\title{
Radon in elementary schools in Tunisia
}

\author{
S. LABIDI ${ }^{1}$, D. AL-AZMI ${ }^{2}$, H. MAHJOUBI ${ }^{1}$, R. BEN SALAH ${ }^{3}$
}

(Manuscript received 4 November 2009, accepted 28 January 2010)

\begin{abstract}
Indoor radon measurements were carried out in 30 elementary schools in Tunis, the capital city of Tunisia, during the winter months of December 2008 to early March 2009. Two classrooms, one each from ground floor and first floor were chosen from each school making a total of 60 classrooms. In some of the classrooms, two detectors (open and closed) were used to measure the concentrations of radon as well as radon and its progeny to allow the calculations of the equilibrium factors. Nuclear track detectors type LR-115 (Kodalpha) were used for the measurements. The results show that the radon concentration levels are low in the range of $6-169 \mathrm{~Bq} \mathrm{~m}^{-3}$ with a mean value of $26.9 \mathrm{~Bq} \mathrm{~m}^{-3}$. The annual effective dose was found to vary between $0.025-0.715 \mathrm{mSv}^{-1}$ for teachers while the range for pupils was from $0.019-0.525 \mathrm{mSv}^{-1}$. These values are within the ICPR recommended values.
\end{abstract}

Keywords: radon measurements / elementary schools / effective dose / equilibrium factor / Tunis / Tunisia

RÉSUMÉ Radon dans des écoles primaires de Tunis.

Les mesures du radon ont été effectuées dans 30 écoles primaires dans le grand Tunis, durant la période (décembre 2008-mars 2009). Deux salles de classe ont été choisies dans chaque école, une au rez de chaussée et l'autre au premier étage, soit un total de 60 salles de classe. La mesure des concentrations de radon ainsi que ses descendants et l'estimation des facteurs d'équilibre ont été effectués à l'aide de deux détecteurs solides de traces nucléaires de type RC-115 (ouvert et fermé). Les résultats montrent que les niveaux de concentration en radon sont faibles de l'ordre de 6 à $169 \mathrm{~Bq} \mathrm{~m}^{-3}$ avec une valeur moyenne de $26,9 \mathrm{~Bq} \mathrm{~m}^{-3}$. La dose efficace annuelle estimée, varie entre 0,025 et $0,715 \mathrm{mSv}^{-1}$ pour les enseignants et entre 0,019 et $0,525 \mathrm{mSv}^{-1}$ pour les élèves. Ces valeurs sont dans la gamme des valeurs recommandées par la CIPR.

\section{Introduction}

Radon $\left({ }^{222} \mathrm{Rn}\right)$ is a naturally occurring, inert radioactive gas formed in the uranium $\left({ }^{238} \mathrm{U}\right)$ decay series. Uranium and all its decay products (up to lead) are solid elements except radon is a noble gas. ${ }^{222} \mathrm{Rn}$ decays to form a series of short-lived radionuclides known as radon daughters or progeny; ${ }^{218} \mathrm{Po},{ }^{214} \mathrm{~Pb},{ }^{214} \mathrm{Bi},{ }^{214} \mathrm{Po}$, until reaching ${ }^{206} \mathrm{~Pb}$ (stable lead).

\footnotetext{
1 Institut Supérieur des Technologies Médicales de Tunis (ISTMT), 9 avenue du docteur Z. Essafi, Tunis 1006, Tunisia. e-mail: labidisalam@yahoo.fr

2 Department of Applied Sciences, College of Technological Studies, Public Authority for Applied Education and Training, PO Box 42325, 70654 Shuwaikh, Kuwait. e-mail: ds.alazmi@paaet.edu.kw / dalazmi@yahoo.co.uk

3 Faculté de Médecine de Sousse, 270 Sahloul II, 4054 Sousse, Tunisia.
} 
Radon is found everywhere in all rocks and soils, outdoors and indoors. Outdoors, radon and its decay products rarely reach high levels because of continual dispersion and dilution. Whereas in indoors, reduced ventilation may cause radon and its decay products to reach levels that are orders of magnitude above the outdoor levels (Khan, 2000). The radon decay products may be attached to ambient aerosols and when inhaled can be retained in the lung and deliver a dose to its walls by alpha particle emission. Therefore, the major risk to health is from the radon progeny rather than the radon progenitor (ICRP, 1993).

As a consequence of the high proportion of time spent indoors and the elevation of indoor radon concentrations relative to outdoor concentrations, most exposure to radon and its decay products occurs indoors. The inhalation of radon and radon decay products is the largest contributor to the natural radiation exposure of the population and a high number of lung cancer cases are reported annually (NCRP, 1984).

\subsection{Radon in schools}

Because many people (as well as children) spend much of their time at home, the home is likely to be the most significant source of radon exposure. Therefore, indoor radon tests should be performed and actions to be taken to reduce the radon concentration levels if they are too high. For most school children and staff, the second largest contributor to their radon exposure is likely to be their school (EPA, 1993).

Early concern about indoor radon focused primarily on the hazard posed in the home. Later on, extensive research on the presence and measurement of radon in schools has been conducted (EPA, 1993). Schools as many buildings (or dwellings) may have high radon levels (Vaupotic, 2002) which depend on the construction materials, quality of buildings as well as the ventilation.

\subsection{Elementary schools in Tunis}

In winter in Tunisia, the windows and doors of classrooms are commonly closed during the teaching hours in order to keep the indoor atmosphere warm. Heating/air-conditioning systems are not used in the schools. This situation results in reduced ventilation and therefore the concentrations of radon and its progeny are expected to be higher compared to when the windows and/or the doors are left open. 


\section{Materials and method}

Radon surveys carried out in homes and work places (including schools) are commonly limited to radon measurements only. However, additional measurements of the radon progeny are required in order to obtain the better estimate of the radon dosimetry, considering that it is the presence of radon progeny in the indoor air is the major contributor to the radiation dose to the lungs and the epithelium layer are concerned. Simultaneous measurements of radon and the radon progeny provide practical estimates of the equilibrium factor $(E F)$, which is an important parameter in the radon dosimetry. It is a common practice to measure radon only and adopt an appropriate $E F$ value (commonly 0.4) in the dose calculation (UNSCEAR, 2000).

Since our present study for radon measurements was planed to be carried out during the winter period when the ventilation rate is poor, measurements aimed at estimating the equilibrium factor $(E F)$ were also considered in some of the classroom so that an idea about such an EF may be obtained.

Solid state nuclear track detectors were used in this survey to provide integrated measurements over a period of 3 months during the cold climate in the investigated classrooms. Kodalpha ${ }^{1}$ radon dosimeters supplied with LR-115 nuclear track films have been selected for this survey. A track detector was kept inside a pre-calibrated cup, which is provided with pin holes at the top side to allow the entry of radon only (as a closed detector). A detector was installed in each classroom for the measurement of indoor radon. In some of the classrooms, an additional detector was placed open (without the cup) to allow the measurements of radon and its progeny, Figure 1. Based on the difference between the two readings of the track density from the two dosimeters (in the investigated classrooms), the equilibrium factor may be determined.

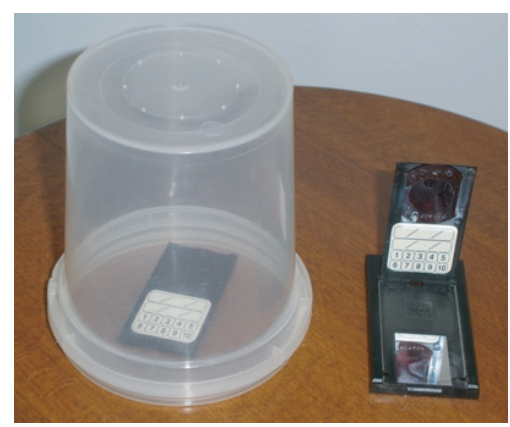

1 DOSIRAD, Paris, France.
Figure 1 - The Kodalpha radon dosimeter kept inside a pre-calibrated cup (provided with pin holes) is used for the measurement of radon only. Otherwise the radon dosimeter is left in the open environment for the measurements of radon and its progeny.

Le dosimètre type «fermé » Kodalpha placé dans un gobelet calibré (percé de nombreux trous) est utilisé pour la mesure du radon seulement. Le dosimètre type "ouvert» est exposé à l'air libre, dans les salles de classe pour la mesure du radon et ses descendants. 


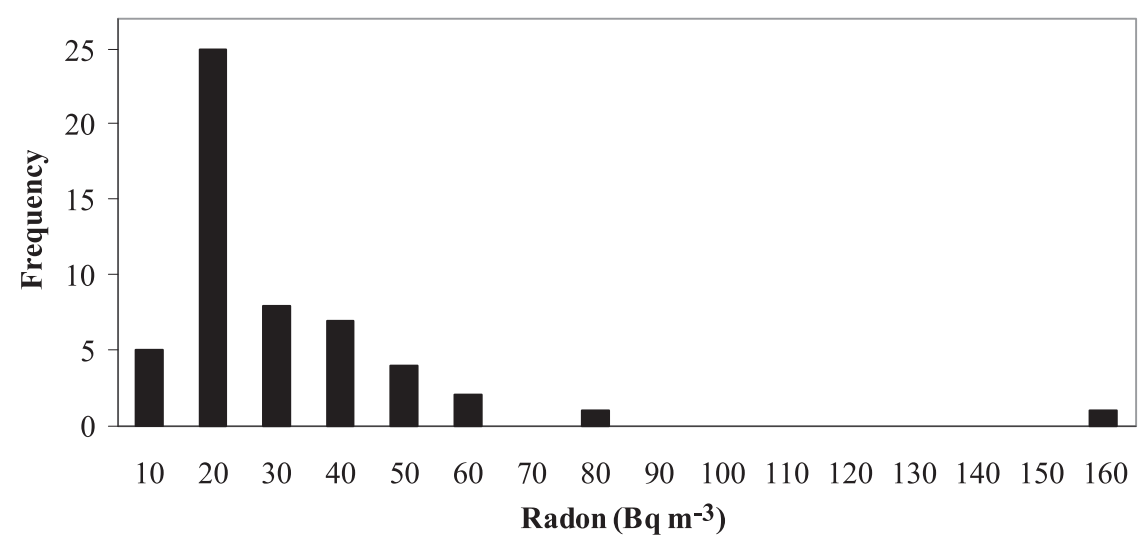

Figure 2 - Frequency distribution of indoor radon concentrations observed in the school classrooms in Tunis.

La fréquence de distribution des concentrations en radon observées dans les salles de classe de l'école à Tunis.

At the end of the exposure period, which lasted for three months (December 2008 to March 2009), the nuclear track detectors were collected and sent to the DOSIRAD laboratory (France) for etching and reading. Different calibrations are used for each set of the open and the closed detectors.

\section{Results and discussions}

The study covered schools within the city of Tunis and from the nearby countryside. Sixty classrooms from 30 schools were covered in this study for the measurements of indoor radon with the closed dosimeters. In each school, one classroom was chosen from the ground floor where the other one was from the first floor, where available. In some of the classrooms (15 classrooms) open dosimeters were used for additional measurements for the radon progeny. However, some of the closed detectors were lost from 7 classrooms and one open detector from a classroom.

The indoor radon concentration for 53 classrooms covered in 28 schools was found to vary in the range $6-169 \mathrm{~Bq} \mathrm{~m}^{-3}$ with a mean value of $26.9 \mathrm{~Bq} \mathrm{~m}^{-3}$. The radon concentration levels are generally low with most values below $80 \mathrm{~Bq} \mathrm{~m}^{-3}$ with only one data of a double value $\left(169 \mathrm{~Bq} \mathrm{~m}^{-3}\right)$. Figure 2 represents the frequency distribution.

The mean value for the indoor radon concentration levels obtained in this work for the schools in Tunis, are lower than the reported values for the indoor radon survey conducted in dwellings all over Tunisia which showed an average mean value of $45 \mathrm{~Bq} \mathrm{~m}^{-3}$ (El May et al., 2004). 


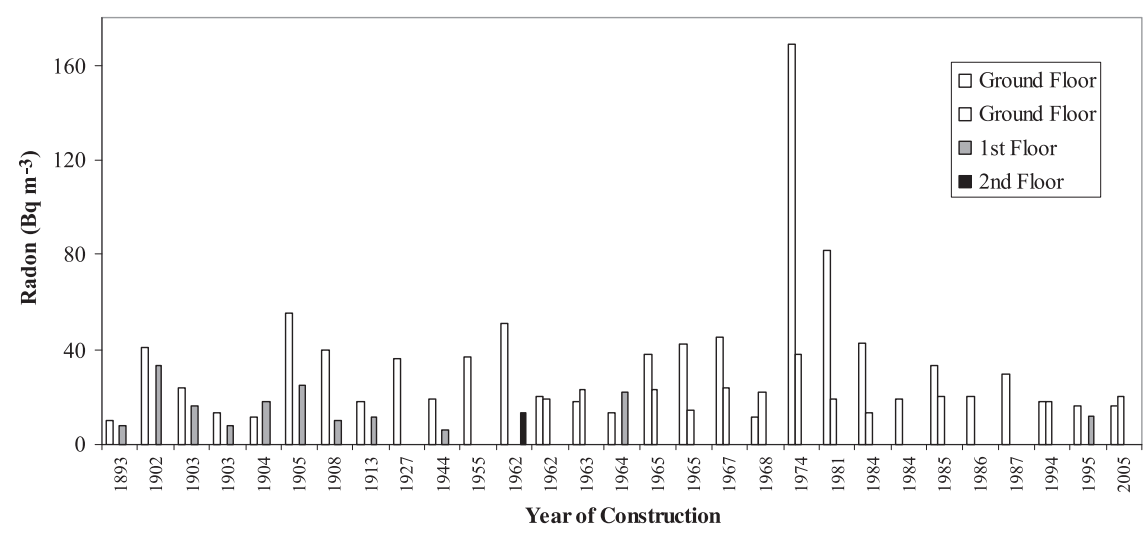

Figure 3 - The radon values as measured in the ground and first floors in schools constructed in various times. In some schools, two classrooms from the ground floor were measured.

Mesure des concentrations de radon au rez-de-chaussée et au premier étage dans des écoles construites à différentes époques. Pour certaines écoles, deux salles de classe au rez-dechaussée ont été mesurés.

\subsection{Radon in different building age and different floors}

Ages of the school buildings encountered in this study vary widely from about five years to more than a century. It is however observed that the old buildings are well maintained. An evaluation of the radon data was carried out to detect if any age dependent factors, such as cracks in the walls due to usage, structural differences (e.g. wall thickness and room size), etc., has any impact on the radon concentration. But as presented in Figure 3, there is no observable correlation between radon concentration and age of building. This may be attributed to the good maintenance of the school buildings. The building materials may also have low concentration of radon precursors or/and low radon exhalation. This result is in contrast to what was observed in a similar study conducted in Amman (Jordan) where some age dependent variations in indoor concentrations were reported in kindergartens (Kullab et al., 1997). However, Kullab et al. (1997) also indicated that the classrooms in the older buildings were relatively smaller in size, have cracks in the floors and walls, and have relatively poor ventilation compared to new kindergartens.

Comparison of radon concentration in ground floor classrooms to those of higher floors shows that radon concentrations are higher on the ground floor except for two cases as shown for each individual school in Figure 3. In Table I, the values for the average radon concentrations are provided for both floors as well as for all classrooms showing that in the ground floor the radon concentration is 


\section{TABLE I}

Radon concentrations in classrooms of different floors.

Concentrations de radon dans les salles de classe à différents étages.

\begin{tabular}{lcccc}
\hline $\begin{array}{c}\text { Classroom } \\
\text { Location }\end{array}$ & $\begin{array}{c}\text { Number of } \\
\text { classrooms }\end{array}$ & Range & Mean & SD \\
\hline Ground floor & 41 & $10-169$ & 30.3 & 26.6 \\
\hline First floor & 11 & $6-33$ & 15.4 & 8.4 \\
\hline Second floor & 1 & - & 13 & 6 \\
\hline All classrooms & 53 & $6-169$ & 26.9 & 24.5 \\
\hline
\end{tabular}

TABLE II

Radon concentrations in schools in different countries.

Concentration de radon dans des écoles de différents pays.

\begin{tabular}{|c|c|c|c|c|}
\hline Country & $\begin{array}{l}\text { Radon concentration } \\
\text { values }\left(\mathrm{Bq} \mathrm{m}^{-3}\right) \\
\text { Mean }(\text { Range) }\end{array}$ & Measurement period & Remarks & Reference \\
\hline $\begin{array}{l}\text { Patras } \\
\text { (Greece) }\end{array}$ & $35 \pm 17(10-89)$ & December to May & Primary schools & $\begin{array}{l}\text { Papaefthymiou } \\
\text { and Georgiou, } 2007\end{array}$ \\
\hline $\begin{array}{l}\text { Lod } \\
\text { (Poland) }\end{array}$ & 17.9 & Winter & $\begin{array}{l}\text { Kindergartens and } \\
\text { schools }\end{array}$ & Bem et al., 1999 \\
\hline $\begin{array}{l}\text { Parma } \\
\text { (Italy) }\end{array}$ & $23.2 \pm 14.8(10-89)$ & Autumn to Spring & $\begin{array}{l}\text { Kindergartens and play } \\
\text { schools }\end{array}$ & Malanca et al., 1997 \\
\hline Kuwait & $18 \pm 6(8-26)$ & September to March & Elementary schools & Maged, 2006 \\
\hline $\begin{array}{l}\text { Zulfi } \\
\text { (Saudi Arabia) }\end{array}$ & $74.67 \pm 3.04$ & & $\begin{array}{l}\text { Kindergartens, play } \\
\text { and elementary schools }\end{array}$ & Al-Mosa, 2007 \\
\hline $\begin{array}{l}\text { Amman } \\
\text { (Jordan) }\end{array}$ & $76.8(40.7-193.5)$ & Winter season & Kindergartens & Kullab et al., 1997 \\
\hline Japan & $\begin{array}{l}30.9 \pm 32.4(4.9-276) \\
35.7 \pm 37.6(5.2-314)\end{array}$ & $\begin{array}{l}\text { October to December } \\
\text { January to March }\end{array}$ & Schools & Oikawa et al., 2006 \\
\hline $\begin{array}{l}\text { Tunis } \\
\text { (Tunisia) }\end{array}$ & $26.9 \pm 24.5(6-169)$ & December to March & Elementary schools & Present work \\
\hline
\end{tabular}

with an average value of $30.3 \mathrm{~Bq} \mathrm{~m}^{-3}$ and the average value for the first floor is about half of that of the ground floor $\left(15.4 \mathrm{~Bq} \mathrm{~m}^{-3}\right)$.

The results presented in Table II are for comparison with schools from varies regions showing that the indoor radon concentration levels in the elementary schools in Tunis are with low values. 


\subsection{Measurements of the equilibrium factors}

For estimating the equilibrium factor $E F$ between radon and its progeny, two detectors open and closed were used simulituously. The calculations provided by DOSIRAD for the equilibrium factor $E F$ are based on finding out the ratio $R$ between the readings of the open and closed radon detectors, then using the Polynomial as follows:

$$
\begin{gathered}
E F=13.235 R^{4}-32.904 R^{3}+30.621 R^{2}-12.323 R+1.8049 \\
\quad \text { for } 0.433<R \leq 0.95 \\
E F=0 \quad \text { if } R<0.433,
\end{gathered}
$$

and

$$
E F=0.98 R^{3}-4.416 R^{2}+7.5759 R-3.7447 \text { for } R \geq 0.95 .
$$

The results from 14 detectors were found to show that the mean value of the equilibrium factor is 0.404 for the classrooms in the ground floor and 0.554 for classrooms in the first floor. The overall mean value is 0.489 for $E F$ for all the classrooms.

\subsection{Effective dose}

From a radiological point of view, radon is a major cause of the dose absorbed by the population (UNSCEAR, 2000) and such a cause increases at places of reduced ventilation such as, for example, the classrooms in winter in Tunis. Therefore, the estimation of the health risk associated with the inhalation of ${ }^{222} \mathrm{Rn}$ and its progeny by the pupils and the teachers inside the classrooms of the elementary schools is important since for people with younger age, lung cancer rates are significantly higher in places where the radon concentration is higher (Pearce and Boyle, 2005).

The annual effective dose $D_{E F F}\left(\mathrm{mSv} \mathrm{y}^{-1}\right)$ to the pupils and teachers were calculated using the relations adopted from UNSCEAR (2000);

$$
D_{E F F}\left(\mathrm{mSv} \mathrm{y}^{-1}\right)=C_{R n}\left(\mathrm{~Bq} \mathrm{~m}^{-3}\right) \times E F \times T\left(\mathrm{~h} \mathrm{y}^{-1}\right) \times 9 \mathrm{nSv} \text { per }\left(\mathrm{Bq} \mathrm{h} \mathrm{m}{ }^{-3}\right)
$$

where $C_{R n}$ is the indoor radon concentration, $T$ is the exposure time in one year and $9 \mathrm{nSv}$ per $\left(\mathrm{Bq} \mathrm{h} \mathrm{m}{ }^{-3}\right)$ is the effective dose coefficient or conversion factor converting radon concentration to effective dose. This value is based on dosimetric model for an adult male of average breathing rate $0.6 \mathrm{~m}^{3} \mathrm{~h}^{-1}$, in indoor of aerosol median diameter of 100-150 nm. Higher dose conversion factor is expected for pupils due to their higher breathing rate. The exposure times per annum are $704 \mathrm{~h}$ (22 hours/week) for pupils and an average of $960 \mathrm{~h}$ for the teachers. The annual 
effective doses were calculated based on these exposure times, the average $E F$ $(=0.49)$, and the values of radon concentrations obtained in this survey. The ranges and means of the effective doses are $0.025-0.715,0.114 \mathrm{mSv} / \mathrm{y}$ and $0.019-0.525,0.084 \mathrm{mSv} \mathrm{y}^{-1}$, for teachers and pupils, respectively. The teachers' estimates may be taken as representative for the pupils as well considering that their breathing rates are higher than the assumed average for adults. The values are, however, less than the ICRP recommended value of $1 \mathrm{mSv} \mathrm{y}^{-1}$ for general public.

\section{Conclusion}

This study present the first set of data on indoor radon measurements in schools in Tunisia. The indoor radon concentration levels in selected elementary schools of Tunis range from 6 to $169 \mathrm{~Bq} \mathrm{~m}^{-3}$ with a mean of $26.9 \mathrm{~Bq} \mathrm{~m}^{-3}$. Although the measurements were conducted during winter, these values are relatively low and do not constitute any radiological concern. The good (relatively large) sizes of the classrooms and the good maintenance have contributed towards such low indoor radon levels. The results also show that the age of building is not an overriding influencing factor on indoor radon concentration if the building is well maintained.

Another significant contribution of the study is that it presents additional measurements that were used to estimate the equilibrium factor $(E F)$ between radon and its decay products. The mean $E F$ obtained in this study (of 0.49 ) is close to the internationally adopted value of 0.4 .

The annual effective dose corresponding to the radon concentration values also vary between 0.025 and $0.715 \mathrm{mSv} \mathrm{y}^{-1}$ for teachers and 0.019 to $0.525 \mathrm{mSv} \mathrm{y}^{-1}$ for pupils. These values are much lower than the limits recommended by ICRP.

Acknowledgement. The authors would like to express their thanks to the Ministry of Education in Tunisia for the cooperation to allow this survey and to the staff of the schools where the measurements were performed.

\section{REFERENCES}

Al-Mosa T.M.A. (2007) Indoor Radon Concentration in Kindergartens, Play- and Elementary Schools in Zulfy City (Saudi Arabia), MSc. Thesis, Department of Physics and Astronomy at the College of Science - King Saud University; October 2007.

Bem H., Bem E.M., Ostrowska M. (1999) Radon Concentrations in Kindergartens and Schools in the Lód-Region of Poland, Rad. Prot. Dosim. 82, 147-149.

El May M.V., Chahed N., Mtimet S. (2004) Radon concentrations in some dwellings of Tunisia, Health Phys. 86, 150-154.

EPA (1993) United States Environmental Protection. Radon Measurement in Schools, EPA 402-R-92014.

ICRP Publication 65 (1993) Protection against radon-222 at home and at work, Ann. ICRP 23(2). 


\section{RADON IN ELEMENTARY SCHOOLS IN TUNISIA}

Khan A.J. (2000) A study of indoor radon levels in Indian dwellings, influencing factors and lung cancer risks, Rad. Meas. 32, 87-92.

Kullab M.K., Al-Bataina B.A., Ismail A.M., Abumurad K.M., Ghaith A. (1997) Study of radon-222 concentration levels inside kindergartens in Amman, Rad. Meas. 28, 699-702.

Maged A.F. (2006) Radon concentrations in elementary schools in Kuwait, Health Phys. 90, 258-262.

Malanca A., Gaidolfi L., Fava R. (1997) Natural radioactivity in kindergartens and play schools of Parma, Italy, Environm. Int. 23, 541-546.

NCRP (1984) National Council on Radiation Protection and Measurements, Evaluation of occupational and environmental exposure to radon and radon daughters, Rapport No. 78.

Oikawa S., Kanno N., Sanada T., Abukawa J., Higuchi H. (2006) A survey of indoor workplace radon concentration in Japan, J. Environm. Rad. 87, 239-245.

Papaefthymiou H., Georgiou C.D. (2007) Indoor radon levels in primary schools of Patras, Greece, Rad. Prot. Dosim. 124, 172-176.

Pearce J., Boyle P. (2005) Examining the relationship between lung cancer and radon in small areas across Scotland, Health \& Place 11, 275-282.

UNSCEAR (2000) United Nations Scientific Committee on the Effects of Atomic Radiation, Report to the General Assembly, Vol. 1, Annex B.

Vaupotic J. (2002) Identification of sources of high radon levels in Slovenian schools, Rad. Prot. Dosim. 102, 75-80. 